Kalusova, L., \& Badura, P. (2020). Differences in the financial structure of Slovak and Czech enterprises operating in machinery manufacturing and equipment industry. Journal of International Studies, 13(1), 155-169. doi:10.14254/2071$8330.2020 / 13-1 / 10$

\title{
Differences in the financial structure of Slovak and Czech enterprises operating in machinery manufacturing and equipment industry
}

\author{
Lenka Kalusova \\ Department of Business Finance, University of Economics in \\ Bratislava \\ Slovakia \\ lenka.kalusova@emba.sk \\ Peter Badura \\ Department of Business Finance, University of Economics in \\ Bratislava \\ Slovakia \\ peter.badura@euba.sk
}

\begin{abstract}
The paper offers a thorough study of the selected factors influencing the financial structure of Slovak and Czech companies operating in the machinery and equipment industry. These factors were broken down into internal factors (profitability, company size, liquidity, assets' structure, business risk, non-debt tax shield and company's age) and the external factors (economic cycle, inflation, interest rate and tax rate). The aim of the paper was to analyze, evaluate and assess whether there were differences in the influence of these factors (i.e. different direction and intensity of their impact) on the financial structure of Slovak and Czech enterprises. The analysis was done for the years 2014 - 2018. The multiple regression analysis was used as the main research method. The research results pointed to the fact that the financial structure of Slovak and Czech companies was affected mainly by the influence of internal corporate factors, and moreover, there were also certain differences between Slovak and Czech enterprises - not only in intensity but even in the direction of action of these factors. Given the internal structure of financing sources and based on our findings, our recommendations were that in the area of financial structure of enterprises, they should focus their attention primarily on corporate liquidity (Slovak enterprises in particular). At the same time, it was clear that the government policy should focus on improving law enforcement in trade relations and also improving the protection of creditors' rights, as business loans were the most used external sources of funding.
\end{abstract}


Keywords: financial structure, internal corporate factors, external factors of macroenvironment, Slovak and Czech enterprises.

JEL Classification: G32, E22, D22.

\section{INTRODUCTION}

Some of the most important areas in financial management of companies are the decisions taken on financial and capital structure. Implications from these decisions are reflected in a longer term and they also affect financial stability of the whole enterprise. The importance of the appropriate financial structure formation can be seen especially in the segment of small and medium-sized enterprises (SMEs). These enterprises have limited options of using certain sources of financing and hence are exposed to limits in forming their financial structure. In this case we mean the problematic availability of some sources of funding (e.g., bank loans). The research by Belás et al. (2014) points to the fact that, although this was a common financing problem of SMEs, the problem has further deepened during the latest economic crisis. In shaping their financial structure, enterprises should take into account a number of factors, which are highlighted by several studies conducted in domestic as well as foreign context. However, many of these studies are only assessing the impact of internal business factors while, in our opinion, external factors of macroenvironment in which enterprises are operating, also play an important role in deciding on the structure of funding sources. For this reason, the aim of our research is to analyze and evaluate the impact of both internal/corporate as well as external macroeconomic factors on the financial structure of Slovak and Czech enterprises. Several studies note that the sector in which enterprises operate is also an important factor affecting financial structure of enterprises (Hall et al., 2000; Singla, 2008; Vatavu, 2013). According to the results of the mentioned studies, companies operating in different sectors have some differences in their financial structure (for enterprises operating in the same sector, there is usually a certain, typical ratio of debt to equity). For this reason, we have decided to study companies operating in the same sector, which is manufacturing of machinery and equipment industry.

Based on the abovementioned facts, we formulate the following research questions:

Is the financial structure of Slovak and Czech companies influenced not only by internal corporate factors but also by external macroeconomic factors (economic cycle, inflation, tax rates and interest rates)?

What is the impact direction and intensity of these factors on the financial structure of enterprises?

Are there any differences in intensity or even in the direction of these factors' influence in the analyzed Slovak and Czech companies?

\section{LITERATURE REVIEW}

Numerous studies deal with the influence of especially internal corporate factors on the financial structure of enterprises. The influence of profitability on the financial structure of enterprises was examined by the authors Herciu and Ogrean (2017). The research results showed a strong correlation between the company's performance and its financial structure, but the direction of impact depended on the sector in which the enterprises were doing the business. Confirming the impact of profitability as one of the factors influencing the financial structure can be also found in the study by Jaisinghani and Kanjilal (2017). The influence of asset structure, business size and non-debt tax shield was also confirmed by the research of Bajramovic (2017) on a sample of enterprises operating in Bosnia and Herzegovina. The impact of the asset structure and profitability on the financial structure of Swiss businesses was proven by the study of Drobetz 
and Fix (2003). In addition, the authors also pointed to the fact that the level of indebtedness of Swiss enterprises was relatively low, despite the fact that they operated in a European banking-oriented system. The influence of selected internal corporate factors on Czech and Bulgarian enterprises was analyzed by Nivorozkhin (2004). The results of his research suggested that there were certain similarities between the Czech and Bulgarian enterprises - as for the impact of the factors studied by the author. Internal corporate factors affecting the financial structure of 79 enterprises (operating in several sectors during 1993 - 2010 in Turkey) were examined by Kakilli Acaravci (2015). According to his findings, the size of the company, the profitability, the asset structure as well as the non-debt tax shield were all important determinants of the financial structure.

Sadly, the aforementioned studies have largely not taken into account the impact of external macroeconomic environment (e.g. the impact of the economic cycle, the effect of inflation, tax rates) in which the companies operate and which, in our opinion, to a considerable extent affects the possibilities of obtaining various forms of funding sources. The impact of selected internal corporate factors and macroenvironment factors on the financial structure was studied by Öztekin (2015) on a sample of 37 countries. In his study, in addition to confirming the impact of selected internal factors, the inflation and sector's indebtedness were also identified as other important factors influencing the financial structure. The relationship between selected factors of macro-environment and financial structures of companies has been studied by Bokpin (2009). The conclusions of the study underline the importance of inflation and the economic cycle as factors determining the financial structure of enterprises. The above results have been confirmed by the study of Jong et al. (2008), who in addition to the impact of the economic cycle and inflation adds other macro-environment factors that affect the financial structure of companies, namely the openness of the economy and the level of legal environment. Impact of macro-environment on the financial structure has been also studied by Booth et al. (2001). According to their findings, the variables that affect the financial structure and indebtedness of American and European companies are also important in developing countries, despite significant differences in institutional factors in these countries. The impact of parallel action of the external macro-environment factors and internal corporate factors on financial structure of the small and medium enterprises has been analyzed by Jõeveer (2005). The main result of the analysis was that especially small and unlisted companies were affected by external factors of the country these factors explain more than $50 \%$ of indebtedness of non-listed companies.

Extensive research on the impact of taxes on the financial structure of enterprises was carried out by Faccio and $\mathrm{Xu}$ (2015). The authors examined the impact of changes in the corporate tax rates in 29 OECD countries during the years 1981 - 2009. The research results point to the fact that there is a correlation between the income tax rate and the indebtedness of the companies. The importance of the country in which businesses operate was confirmed by the study of Salameh et al. (2012). These authors conducted their research on a sample of companies operating in Saudi Arabia in 2004 - 2009. According to the results of their study, there is not any statistically significant correlation among the corporate indebtedness, the asset structure, the risk and performance of the analyzed companies. The authors explain these findings by the specifics of the system and the nature of the country's economy in which the enterprises operate (according to the Shari'ah Principle, companies operating in Islamic countries do not use classic interestrate borrowed sources to finance their activities, as there is a strict ban on paying and receiving interest that is considered to be excessive). In addition, one of the most important principles is the prohibition of excessive risk-taking (Archer and Karim, 2013).

Based on the abovementioned researches, we decided to focus on the analysis of factors affecting the financial structure of companies, under the conditions of Slovak and Czech enterprises. Since several studies point to differences in the financial structure of companies operating in different sectors, we have focused only on the machinery and equipment industry. As far as we know, such research, which would include an 
examination of the impact of internal business factors as well as external factors of the macro environment, has not yet been conducted in Slovakia and the Czech Republic.

Both countries are in the Central European region. They do have similar historical development, very close cultural and intellectual values that they profess, and the same interests in the area of closer panEuropean integration. Slovakia and the Czech Republic joined the European Union together in 2004. They are also similar in economic terms - in terms of the structure of individual industries, relatively high trade openness, similar GDP per capita and both are tight to the German economy. These are the reasons why we have focused on a more detailed analysis of these two countries.

The aim was to find out whether the financial structure of Slovak and Czech companies and the influence of selected factors on the financial structure is relatively the same, or whether there are some interesting differences in the effects of these factors. These differences might be found not only in the intensity but also in the direction of action. Given the limited scope of the text, the basic economic characteristics of both countries are shown in the following table.

Table 1

GDP and its development at current prices (in millions of $€$ and in \%, 2010-2018)

\begin{tabular}{|l|c|c|c|c|c|r|r|r|r|}
\hline GEO/TIME & $\mathbf{2 0 1 0}$ & $\mathbf{2 0 1 1}$ & $\mathbf{2 0 1 2}$ & $\mathbf{2 0 1 3}$ & $\mathbf{2 0 1 4}$ & $\mathbf{2 0 1 5}$ & $\mathbf{2 0 1 6}$ & $\mathbf{2 0 1 7}$ & $\mathbf{2 0 1 8}$ \\
\hline $\begin{array}{l}\text { European Union - 28 } \\
\text { countries }\end{array}$ & 12845663 & 13235225 & 13501734 & 13615091 & 14091451 & 14854106 & 14985292 & 15409861 & 15901388 \\
\hline Czech Republic & 156718 & 164041 & 161434 & 157742 & 156660 & 168473 & 176370 & 191722 & 207570 \\
\hline Slovakia & 68093 & 71214 & 73484 & 74355 & 76256 & 79758 & 81038 & 84517 & 89721 \\
\hline \% change of GDP & $\mathbf{2 0 1 0}$ & $\mathbf{2 0 1 1}$ & $\mathbf{2 0 1 2}$ & $\mathbf{2 0 1 3}$ & $\mathbf{2 0 1 4}$ & $\mathbf{2 0 1 5}$ & $\mathbf{2 0 1 6}$ & $\mathbf{2 0 1 7}$ & $\mathbf{2 0 1 8}$ \\
\hline $\begin{array}{l}\text { European Union - 28 } \\
\text { countries }\end{array}$ & - & $3.03 \%$ & $2.01 \%$ & $0.84 \%$ & $3.50 \%$ & $5.41 \%$ & $0.88 \%$ & $2.83 \%$ & $3.19 \%$ \\
\hline Czech Republic & - & $4.67 \%$ & $-1.59 \%$ & $-2.29 \%$ & $-0.69 \%$ & $7.54 \%$ & $4.69 \%$ & $8.70 \%$ & $8.27 \%$ \\
\hline Slovakia & - & $4.58 \%$ & $3.19 \%$ & $1.19 \%$ & $2.56 \%$ & $4.59 \%$ & $1.61 \%$ & $4.29 \%$ & $6.16 \%$ \\
\hline
\end{tabular}

Source: Eurostat

Table 1 contains the information on GDP at current prices and its development since 2010. As we can see, in absolute terms, the Czech Republic shows almost double the level of GDP compared to Slovakia. However, this absolute value does not provide comparable information, so the table below (Table 2) shows the development of GDP per capita. Although we can see that the direction of GDP development in Slovakia and the Czech Republic is the same, the intensity of its fluctuations in individual years is different. The GDP grew significantly in 2011, compared to 2010, but in 2012 the pace of economic growth slowed down. While the economy in Slovakia continued to grow, albeit at a slower pace, the Czech economy saw a $1.59 \%$ decline in its performance. Likewise, the Czech economy continues in its negative performance for the following two years, while in Slovakia there is a growth. In 2015, the Czech Republic's economic performance had reversed and started to rise at significant year-on-year rates (e.g. $7.54 \%$ in 2015 compared to 2014). An increase in the GDP rate of growth can be observed in the monitored periods also in Slovakia.

Table 2

Real GDP per capita (years 2010 - 2018)

\begin{tabular}{|l|c|c|c|c|c|c|c|c|c|}
\hline GEO/TIME & $\mathbf{2 0 1 0}$ & $\mathbf{2 0 1 1}$ & $\mathbf{2 0 1 2}$ & $\mathbf{2 0 1 3}$ & $\mathbf{2 0 1 4}$ & $\mathbf{2 0 1 5}$ & $\mathbf{2 0 1 6}$ & $\mathbf{2 0 1 7}$ & $\mathbf{2 0 1 8}$ \\
\hline European Union - 28 countries & 25500 & 25900 & 25730 & 25750 & 26140 & 26680 & 27140 & 27780 & 28280 \\
\hline Czechia & 14900 & 15200 & 15060 & 14980 & 15370 & 16160 & 16520 & 17200 & 17620 \\
\hline Slovakia & 12540 & 12980 & 13200 & 13270 & 13620 & 14270 & 14550 & 14970 & 15560 \\
\hline
\end{tabular}

Source: Eurostat 
As can be seen in Table 2, the Czech Republic has slightly higher GDP per capita compared to Slovakia. However, both countries are below the EU average.

Table 3

Price increases (HICP) in Slovakia and the Czech Republic (years 2010 - 2018)

\begin{tabular}{|l|r|r|r|r|r|r|r|r|r|}
\hline GEO/TIME & \multicolumn{1}{|c|}{$\mathbf{2 0 1 0}$} & \multicolumn{1}{|c|}{$\mathbf{2 0 1 1}$} & \multicolumn{1}{|c|}{$\mathbf{2 0 1 2}$} & \multicolumn{1}{|c|}{$\mathbf{2 0 1 3}$} & \multicolumn{1}{|c|}{$\mathbf{2 0 1 4}$} & \multicolumn{1}{|c|}{$\mathbf{2 0 1 5}$} & \multicolumn{1}{|c|}{$\mathbf{2 0 1 6}$} & \multicolumn{1}{c|}{$\mathbf{2 0 1 7}$} & $\mathbf{2 0 1 8}$ \\
\hline European Union - 28 countries & 2.1 & 3.1 & 2.6 & 1.5 & 0.6 & 0.1 & 0.2 & 1.7 & 1.9 \\
\hline Czechia & 1.2 & 2.2 & 3.5 & 1.4 & 0.4 & 0.3 & 0.6 & 2.4 & 2.0 \\
\hline Slovakia & 0.7 & 4.1 & 3.7 & 1.5 & -0.1 & -0.3 & -0.5 & 1.4 & 2.5 \\
\hline
\end{tabular}

Source: Eurostat

As for the consumer prices, we can conclude from the available data that the growth rate of prices in Slovakia and the Czech Republic is significantly different. In the Czech Republic, the consumer prices were gradually increasing since 2010 until 2013, when the inflation reached the highest level (3.5\%). The subsequent period was characterized by a decline in consumer prices, but in 2017 and 2018, it rose again above $2 \%$ level. In Slovakia, unlike the Czech Republic, we observe that during three years period (2014 2016) there has been a negative rate of consumer prices growth, i.e. deflation.

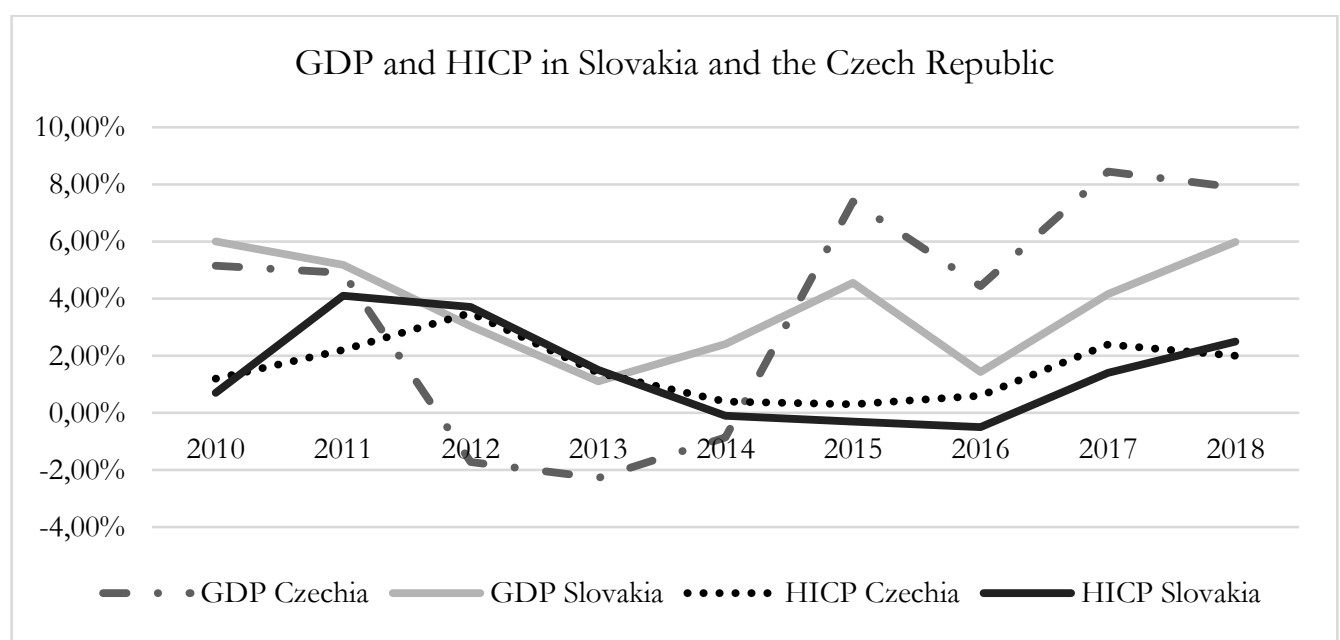

Figure 1. GDP and HICP in Slovakia and the Czech Republic (years 2010 - 2018) Source: Eurostat

Table 4

Structure of enterprises by the size category (years 2010 - 2017)

\begin{tabular}{|c|c|c|c|c|c|c|c|c|c|}
\hline \multirow{6}{*}{ Czechia } & SIZE & 2010 & 2011 & 2012 & 2013 & 2014 & 2015 & 2016 & 2017 \\
\hline & micro & $95.76 \%$ & $95.94 \%$ & $95.99 \%$ & $96.01 \%$ & $96.05 \%$ & $96.03 \%$ & $96.05 \%$ & $96.00 \%$ \\
\hline & small & $3.42 \%$ & $3.26 \%$ & $3.20 \%$ & $3.18 \%$ & $3.15 \%$ & $3.15 \%$ & $3.13 \%$ & $3.17 \%$ \\
\hline & medium & $0.68 \%$ & $0.66 \%$ & $0.66 \%$ & $0.66 \%$ & $0.66 \%$ & $0.66 \%$ & $0.66 \%$ & $0.68 \%$ \\
\hline & SME total & $99.86 \%$ & $99.86 \%$ & $99.86 \%$ & $99.85 \%$ & $99.85 \%$ & $99.84 \%$ & $99.85 \%$ & $99.84 \%$ \\
\hline & big & $0.14 \%$ & $0.14 \%$ & $0.14 \%$ & $0.15 \%$ & $0.15 \%$ & $0.16 \%$ & $0.15 \%$ & $0.16 \%$ \\
\hline \multirow{6}{*}{ Slovakia } & SIZE & 2010 & 2011 & 2012 & 2013 & 2014 & 2015 & 2016 & 2017 \\
\hline & micro & $95.68 \%$ & $96.00 \%$ & $96.46 \%$ & $96.60 \%$ & $96.68 \%$ & $96.53 \%$ & $97.00 \%$ & $96.98 \%$ \\
\hline & small & $3.63 \%$ & $3.32 \%$ & $2.87 \%$ & $2.71 \%$ & $2.67 \%$ & $2.80 \%$ & $2.32 \%$ & $2.36 \%$ \\
\hline & medium & $0.57 \%$ & $0.55 \%$ & $0.54 \%$ & $0.56 \%$ & $0.52 \%$ & $0.54 \%$ & $0.55 \%$ & $0.53 \%$ \\
\hline & SME total & $99.88 \%$ & $99.87 \%$ & $99.87 \%$ & $99.87 \%$ & $99.88 \%$ & $99.88 \%$ & $99.88 \%$ & $99.88 \%$ \\
\hline & big & $0.12 \%$ & $0.13 \%$ & $0.13 \%$ & $0.13 \%$ & $0.12 \%$ & $0.12 \%$ & $0.12 \%$ & $0.12 \%$ \\
\hline
\end{tabular}

Source: Eurostat

Note: The data for 2018 have not yet been published in the Eurostat database. 
Regarding the size category of enterprises, the sector structure is very similar in Slovakia and the Czech Republic. Approximately $99.85 \%$ of enterprises are small and medium-sized enterprises while approximately $0.15 \%$ are big companies.

Several studies point to the fact that the industry in which the company operates is one of the factors affecting its financial structure. Therefore, in our paper we focused on one particular sector, namely SK (CZ) NACE 28 - "Manufacture of machinery and equipment". This industry contributes significantly to the total industrial production revenues. According to the Statistical Office of the Slovak Republic (2018), the share of manufacture of machinery and equipment in the total industrial output of the Slovak Republic is $6.54 \%$ while in the Czech Republic this share represents $8.17 \%$.

In view of the above stated facts, and since we have been able to obtain data from both, Slovakia and the Czech Republic, we have decided to analyze these two countries and their machinery and equipment industry.

\section{METHODOLOGY}

The financial statements required for these studies have been obtained from the Cribis and Albertina databases. We have chosen a number of selection criteria for selecting the companies. The primary criterion was the affiliation of enterprises to the industry - we have chosen SK NACE (CZ NACE) C - Industrial manufacturing, Group 28 - Manufacture of machinery and equipment. Further, from all these companies, we have selected just the legal entities - capital companies. We have studied data from annual financial statements for the years 2014 - 2018. In this 5 years period we have gained access to and consequently analyzed 3,750 financial statements of Czech companies and 1,465 financial statements of Slovak enterprises. Only enterprises that were actively operating in the market were included in the test sample. By setting criteria for the studied enterprises and after exclusion of companies whose financial statements were incorrect, our total sample group consists of 750 Czech and 293 Slovak enterprises. The direction and intensity of selected factors influence on the financial structure of the surveyed enterprises have been analyzed by the multiple regression analysis models:

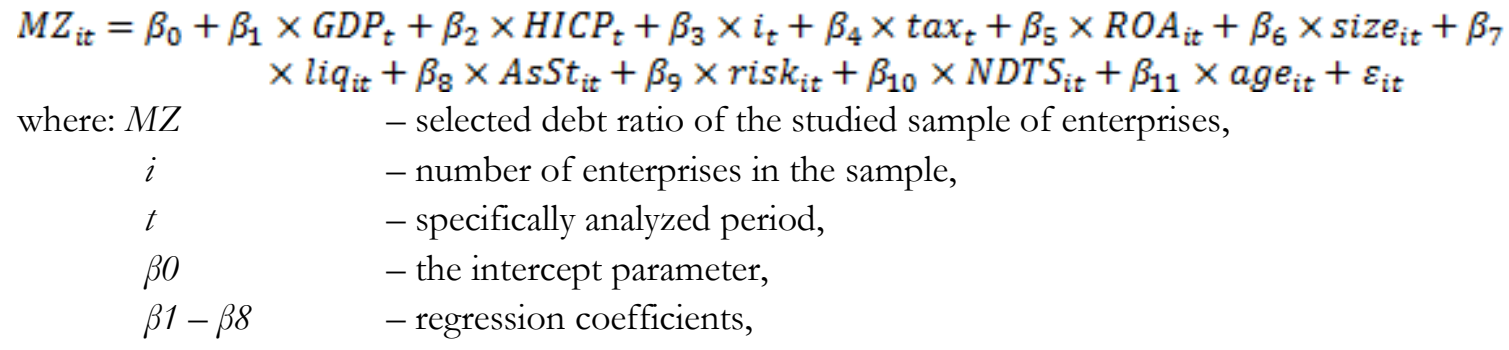
the size of the enterprise, liq - liquidity, AsSt - assets structure, risk - risk level of the company, NDTS - non-debt tax shield, age- the number of years since the company's establishment to the observation date,

sit - random errors.

The direction of impact of selected factors is determined by the regression coefficients. If the sign of the regression coefficient is positive, there is a positive correlation between the independent variable and the indebtedness of the companies. A negative sign would mean a negative correlation. The intensity and statistical significance of the examined factors are being measured by the $\mathrm{p}$-value and assessed in accordance 
with the standards used in analogous foreign researches (e. g. Korajaczyk \& Levy, 2001; Bhaird \& Lucey, 2010).

\section{Dependent variable}

In the model studied by us as the dependent variable appears to be the financial structure of enterprises. In the research by the corporate financial structure, we understand the structure of the total financial sources by which the enterprise is being funded. In this research, it has been decided to test the impact of selected variables on several levels of indebtedness. First, it is the impact of selected factors on the total debt (designed as borrowed capital to total assets). However, since total debt is composed of several levels of indebtedness, and because several studies point to the fact that the influence of the selected factors on the total (and also e.g. credit) indebtedness may be different (Hall et al., 2000; Bevan and Danbolt, 2002; Jõeveer, 2005), we decided to examine the impact of selected internal corporate factors and external macro factors even on the short-term debt (short-term borrowed funding sources to total assets), long-term indebtedness (long-term borrowed capital to total assets) and credit debt (bank loans to total assets of enterprises).

Table 5

The average values of debt indicators for the sample of enterprises in $2018(\%)$

\begin{tabular}{|l|c|c|c|c|c|c|}
\hline Country & \multicolumn{3}{|c|}{ Slovak enterprises } & \multicolumn{3}{c|}{ Czech enterprises } \\
\hline Indicator & Q1 & Q2 & Q3 & Q1 & Q2 & Q3 \\
\hline Total indebtedness & 36.21 & 62.13 & 85.15 & 22.27 & 46.26 & 71.79 \\
\hline Long-term indebtedness & 0.15 & 1.38 & 10.42 & 0.00 & 1.45 & 12.22 \\
\hline Credit indebtedness & 0.00 & 0.00 & 6.28 & 10.42 & 0.00 & 12.83 \\
\hline
\end{tabular}

Note: Q1 - lower quartile; Q2 - median; Q3 - upper quartile

Source: own processing by authors.

Table 5 shows descriptive statistics of selected levels of indebtedness that were studied. When comparing the financial structure of Slovak and Czech companies, it is obvious that the Slovak median enterprise is indebted significantly more $(62.13 \%)$ than the Czech median enterprise (46.26\%). Higher levels of total indebtedness can also be observed in the lower and upper quartile of the sample of enterprises. Although such levels of the total indebtedness of median enterprises could be evaluated positively, it is clear from the table that the internal structure of total indebtedness points to some abnormalities. The total debts of the studied Slovak and Czech companies were mainly of a short-term nature; the companies involved in the manufacture of machinery and equipment industry used minimum of long-term borrowed capital (a Slovak median company had long-term indebtedness of only $1.38 \%$ and a Czech median enterprise had just slightly higher long-term indebtedness of $1.45 \%$ ). The problem of financing the company mostly by short-term debts closely correlates with the ability of the company to repay the debts. Such internal debt structure puts pressure on the ability to pay all the liabilities on time so businesses need to deal adequately with liquidity and its assurance.

Some other differences between Slovak and Czech's companies operating in the manufacture of machinery and equipment industry can also be found in their credit indebtedness. Although a median company mostly does not use the credit sources, $25 \%$ of Slovak enterprises have credit indebtedness higher than $6.28 \%$ and $25 \%$ of Czech companies have credit indebtedness of more than $12.83 \%$.

Based on the abovementioned facts, we can conclude that the financial structure of Slovak enterprises, especially with the view of their internal structure of borrowed capital, is not favourable. The main reason for such inappropriate financial structure is the high demand for banks and their strict credit standards for certain business entities (Belás et al., 2015; Kozubíková et al., 2015). An alternative to obtaining financial 
sources from bank institutions would be to raise the capital through the capital market. Unfortunately, the Slovak capital market is inefficient and does not fulfil its basic functions, as it was mentioned by several authors (Sivák, 2001; Bajus, 2008; Baláž, 2010; Hrvol'ová and Badura, 2014). That is the reason why raising the capital through the issue of shares or bonds is very demanding and why this option is currently used by businesses to a minimum.

\section{Independent variables}

When selecting the factors, which as we assume affect the financial structure of the studied Czech and Slovak enterprises, we based our selection on a study of numerous domestic and foreign researches dealing with the issue of factors determining the financial structure of enterprises. The aforementioned factors are generally divided into two main groups - the external macro-environment factors and internal corporate factors. The summary of studied determinants, as well as the way of their expression, is listed in Table 6 .

Table 6

The summary of studied determinants of financial structure and the way of their expression

\begin{tabular}{|c|c|c|}
\hline Independent variables & Indicator & $\begin{array}{l}\text { Researches that confirm the statistical } \\
\text { significance of the factor }\end{array}$ \\
\hline Economic cycle & GDP growth & Frank, Goyal, 2004 \\
\hline Inflation & HICP & $\begin{array}{l}\text { Demirgüç-Kunt, Maksimovic, 1998; Clayman, } \\
\text { Fridson, Troughton, } 2008\end{array}$ \\
\hline Interest rate & $\begin{array}{l}\text { Average interest rates on loans to } \\
\text { enterprises }\end{array}$ & Bokpin, 2009 \\
\hline Corporate tax rate & $(\mathrm{EBT}-$ net profit) / EBT & Krištofík, 2002; Bauer, 2004 \\
\hline Profitability & Profit before tax / total assets & Nivorožkin, 2004 Bokpin, 2009 \\
\hline Size of a company & Natural logarithm of turnover & $\begin{array}{l}\text { Nguyen, Ramachandran, 2006; Hailu, } \\
\text { Jeffrey, Goddard, } 2007\end{array}$ \\
\hline Liquidity & $\begin{array}{l}\text { Current assets / short term } \\
\text { liabilities }\end{array}$ & Ramalho da Silva, 2009; Moosa, Li, 2012 \\
\hline Assets structure & Tangible fixed assets / total assets & Jõeveer 2006; Heyman, Deloof, Ooghe, 2008 \\
\hline Business risk & Taffler model & $\begin{array}{l}\text { DeAngelo, Masulis, 1980; Titman, Wessels, } \\
1988\end{array}$ \\
\hline Non-debt tax shield & Depreciation / total assets & $\begin{array}{l}\text { Sogorb - Mira, 2005;Režňáková, Svoboda, } \\
\text { Polednáková, 2010; Ameer, } 2013\end{array}$ \\
\hline Age of the company & $\begin{array}{l}\text { The number of years since the } \\
\text { company's establishment to the } \\
\text { observation date }\end{array}$ & Klapper, Sarria-Allende, Sulla, 2002 \\
\hline
\end{tabular}

\section{EMPIRICAL RESULTS AND DISCUSSION}

Before the examination of selected factors' impact on the corporate financial structure we investigate first whether there is not any colinearity among the factors. In the case of the colinearity occurrence the results of the analysis would lose the informative value. By a strong connection between the factors we understand when it applies that $\mid \mathrm{r}$ xixj $\mid \geq 0.7$ for any of the coefficients. 
The study of the relationship tightness among the independent variables in the Slovak sample of enterprises

\begin{tabular}{|l|r|r|r|r|r|r|r|r|c|r|r|}
\hline & \multicolumn{1}{c|}{ GDP } & \multicolumn{1}{c|}{ HICP } & \multicolumn{1}{c|}{$\mathrm{i}$} & tax & \multicolumn{1}{c|}{ ROA } & \multicolumn{1}{c|}{ size } & liq & AsStr & risk & NDTS & age \\
\hline GDP & 1.0000 & & & & & & & & & & \\
\hline HICP & 0.6344 & 1.0000 & & & & & & & & & \\
\hline $\mathrm{i}$ & -0.0011 & -0.0214 & 1.0000 & & & & & & & & \\
\hline tax & -0.0067 & -0.0263 & -0.0076 & 1.0000 & & & & & & & \\
\hline ROA & 0.0219 & 0.0147 & -0.0157 & 0.0184 & 1.0000 & & & & & & \\
\hline size & 0.0087 & -0.0014 & 0.0173 & 0.0177 & 0.0909 & 1.0000 & & & & & \\
\hline liq & -0.0381 & -0.0195 & -0.0013 & -0.0161 & -0.0152 & -0.3155 & 1.0000 & & & & \\
\hline AsStr & 0.0054 & 0.0099 & 0.001 & -0.0029 & -0.126 & 0.3320 & -0.1195 & 1.0000 & & & \\
\hline risk & 0.0161 & 0.0129 & -0.0081 & -0.0130 & 0.1972 & -0.2003 & 0.6096 & -0.1208 & 1.0000 & & \\
\hline NDTS & 0.0432 & 0.0842 & 0.0052 & 0.0259 & -0.0718 & -0.025 & -0.0508 & 0.1713 & -0.0296 & 1.0000 & \\
\hline age & -0.0220 & 0.114 & 0.0017 & 0.0485 & 0.0043 & -0.0204 & -0.0142 & -0.0252 & -0.0472 & -0.0059 & 1.0000 \\
\hline
\end{tabular}

Source: own processing by authors.

The correlation matrix for the group of Czech enterprises is in Table 8. The testing results of the relations' tightness among the different variables in all groups show that there are not any that would be strongly dependent on each other.

Table 8

The study of the relationship tightness among the independent variables in the Czech sample of enterprises

\begin{tabular}{|l|r|r|r|r|r|r|r|r|r|r|r|}
\hline & \multicolumn{1}{c|}{ GDP } & \multicolumn{1}{c|}{ HICP } & \multicolumn{1}{c|}{$\mathrm{i}$} & \multicolumn{1}{c|}{ tax } & \multicolumn{1}{c|}{ ROA } & \multicolumn{1}{c|}{ size } & liq & AsStr & risk & NDTS & age \\
\hline GDP & 1.0000 & & & & & & & & & & \\
\hline HICP & 0.6883 & 1.0000 & & & & & & & & & \\
\hline $\mathrm{i}$ & -0.0249 & -0.0176 & 1.0000 & & & & & & & & \\
\hline tax & 0.0322 & 0.0298 & 0.0001 & 1.0000 & & & & & & & \\
\hline ROA & 0.0200 & 0.0164 & -0.0003 & 0.0010 & 1.0000 & & & & & & \\
\hline size & -0.0043 & 0.0067 & 0.0291 & 0.0106 & 0.0221 & 1.0000 & & & & & \\
\hline liq & 0.0161 & 0.0164 & -0.0019 & -0.0032 & 0.0207 & -0.1615 & 1.0000 & & & & \\
\hline AsStr & 0.0079 & -0.0117 & 0.0155 & 0.0056 & 0.0085 & 0.2804 & -0.0387 & 1.0000 & & & \\
\hline risk & 0.0136 & 0.0150 & -0.001 & -0.002 & -0.0145 & -0.0797 & 0.9441 & -0.0285 & 1.0000 & & \\
\hline NDTS & -0.0159 & -0.0148 & 0.0077 & 0.0068 & -0.0014 & 0.0747 & -0.0206 & 0.3691 & -0.0148 & 1.0000 & \\
\hline age & -0.1117 & -0.0629 & -0.0208 & 0.0142 & 0.0048 & 0.1476 & -0.0376 & 0.0543 & -0.0369 & -0.0428 & 1.0000 \\
\hline
\end{tabular}

Source: own processing by authors.

The summary of the selected factors' direction and intensity on the financial structure of the studied Czech and Slovak enterprises is presented in Table 9. There are also presented coefficients of these factors and their statistical significance.

The results of our research indicate interesting findings concerning the factors affecting the financial structure of Slovak and Czech enterprises. Although the direction of action of more factors is identical, we can find here also some differences - both, as in the intensity of action of these factors, and in some cases even in the direction of their influence. 
Table 9

Summary of direction and intensity of analyzed factors on the financial structure of the studied enterprises

\begin{tabular}{|c|c|c|c|c|}
\hline \multirow{2}{*}{ Independent variable } & \multicolumn{2}{|c|}{ Total debt } & \multicolumn{2}{|c|}{ Short-term debt } \\
\hline & SK & CZ & SK & $\mathrm{CZ}$ \\
\hline Economic cycle & -0.226857 & -17.432034 & -0.171868 & -10.331982 \\
\hline Inflation & 0.119983 & 28.087711 & -0.309240 & 30.592721 \\
\hline Interest rates & -0.000024 & 0.002549 & -0.000018 & 0.001524 \\
\hline Tax rate & 0.010195 & -0.179006 & -0.005922 & -0.119471 \\
\hline Profitability & $-0.431326^{* * *}$ & $-1.069733^{* * *}$ & $-0.385486^{* * *}$ & $-0.381867 * * *$ \\
\hline Size & $-0.023924 * * *$ & $-9.785204 * * *$ & $-0.036942 * * *$ & $-6.045435^{* * *}$ \\
\hline Liquidity & $-0.003163 * * *$ & $-0.175769^{* * *}$ & $-0.003698^{* * *}$ & $-0.115593 * * *$ \\
\hline Asset structure & -0.016451 & 4.7973 & $-0.222386^{* * *}$ & 2.9390 \\
\hline Risk level & $-0.029565^{* * *}$ & $1.454055^{* * *}$ & $-0.022129 * * *$ & $0.956730 * * *$ \\
\hline Non-debt tax shield & $0.306018^{* * *}$ & -9.866635 & 0.155634 & -6.192147 \\
\hline Age & -0.006396 & 0.039092 & -0.003139 & 0.009325 \\
\hline Adj. R square & 0.1620 & 0.1971 & 0.1586 & 0.1928 \\
\hline $\mathrm{F}$ & $9.89 \times 10^{-48}$ & $3.6 \times 10^{-208}$ & $1.42 \times 10^{-46}$ & $6 \times 10^{-203}$ \\
\hline \multirow{2}{*}{ Independent variable } & \multicolumn{2}{|c|}{ Long-term debt } & \multicolumn{2}{|c|}{ Credit debt } \\
\hline & $\mathrm{SK}$ & $\mathrm{CZ}$ & SK & $\mathrm{CZ}$ \\
\hline Economic cycle & -0.044408 & -7.100052 & -0.056153 & -0.147954 \\
\hline Inflation & 0.383167 & -2.505010 & $0.389445^{* *}$ & 0.276868 \\
\hline Interest rates & -0.000006 & 0.001025 & -0.000004 & -0.000045 \\
\hline Tax rate & $0.016203^{* * *}$ & -0.059534 & $0.006816^{* *}$ & 0.000983 \\
\hline Profitability & $-0.047282 * *$ & $-0.687866^{* * *}$ & $-0.039641 * *$ & -0.000314 \\
\hline Size & $0.017539 * * *$ & $-3.739853^{* * *}$ & $0.005702^{*}$ & $0.008768^{* *}$ \\
\hline Liquidity & $0.000608^{* *}$ & $-0.060177 * * *$ & 0.000118 & -0.000045 \\
\hline Asset structure & $0.202859 * * *$ & 1.858362 & $0.135221 * * *$ & $0.121585^{* * *}$ \\
\hline Risk level & $-0.007172 * *$ & $0.497325^{* * *}$ & $-0.004071 *$ & 0.000294 \\
\hline Non-debt tax shield & $0.160424 * * *$ & -3.674487 & -0.049759 & $-0.591826^{* * *}$ \\
\hline Age & -0.003316 & 0.029768 & $-0.004102 * *$ & $-0.004666 * * *$ \\
\hline Adj. R square & 0.1499 & 0.1762 & 0.1038 & 0.0273 \\
\hline $\mathrm{F}$ & $1.2 \times 10^{-43}$ & $4 \times 10^{-183}$ & $1.02 \times 10^{-28}$ & $1.1 \times 10^{-23}$ \\
\hline
\end{tabular}

Note: $* * *$ indicates significance at the $1 \%$ level, ** indicates significance at the $5 \%$ level and $*$ indicates significance at the $10 \%$ level.

Source: compiled by authors.

First, we can conclude that the models we chose were statistically significant $(\mathrm{F}<0.01)$ based on the $\mathrm{F}$ test results. In general, we can say that the impact of external macro-environment factors on the financial structure of Slovak or Czech companies operating in the manufacture of machinery and equipment industry has not been confirmed. In the case of credit indebtedness of Slovak companies only the inflation and tax rates showed to be a statistically significant factor. We found a positive correlation between inflation and corporate debt. This finding is in line with the compromise theory. The price level is rising especially in times of economic boom, which is also favorable to new investments. As a result, a number of enterprises do not have sufficient resources to finance these investments so they opt for taking a loan and repaying the debt by money which value is continuosly decreasing. It also applies that there is a positive correlation between tax rates and credit indebtedness. In this case, we assume that business entities prefer financing through interest-based borrowed funds (prior to equity financing) due to the existence of tax shield. Although raising the credit sources leads to an increase in interest costs, on the other side it is a taxdeductible cost so the tax base and thus the tax paid is reduced. A positive correlation was also observed between the tax rate and the long-term indebtedness of the studied Slovak enterprises. 
The impact of almost all internal corporate factors is statistically highly significant. The significance of these factors depends on the indebtedness level of the studied companies (which also confirms our statement that it is important to monitor the impact of these factors not only on total indebtedness but also on partial debt ratios). There is a negative correlation between profitability, size and liquidity of the companies on one side and the total and short-term indebtedness of Slovak and Czech enterprises on the other side. The research results have shown that with the increase in the size category of enterprises the debt of these enterprises is decreasing. We believe that larger companies can generate a higher volume of own funds and therefore do not have to raise their indebtedness level in financing their business plans but can do so through their own resources. These findings are consistent with the behaviour of enterprises in forming their financial structure according to the hierarchical order theory (companies prefer their own internal sources to finance and they reach to external sources just in the second row). The availability of internal sources is directly affected by the company's ability to generate profit, its liquidity and its size. Our research results on these three factors are consistent with the research results of several foreign authors (Sogorb-Mira, 2005; Heyman et al., 2008; Harrison \& Widjaja, 2014).

Significant differences, not only in intensity but even in the direction of action, can be observed in the case of the current risk level. There is an inverse relationship between the financial structure of Slovak enterprises and risk but as for the Czech enterprises a statistically significant positive correlation has been detected. In the case of Slovak enterprises, with an increasing level of risk, their total debt is decreasing. We assume that the higher level of risk leads to a decrease in the volume of business loans from suppliers (as they are not willing to risk their money) and at the same time there is a decline in the volume of bank loans used (which was statistically confirmed by a negative correlation between credit indebtedness and the risk). In such case banks, using their creditworthiness models, find that lending to such companies would be very risky. They either would not provide the financial sources at all, or they would provide the funds just at the expense of significantly higher interest rates. On the other side, such high interest rates are not acceptable to the company, so after all it would refuse to take such loan. In the case of Czech enterprises with an increase in the level of risk, their level of indebtedness is rising as well. This is where we see the main difference between the behaviour of Slovak and Czech enterprises. The behaviour of Czech companies could be explained by the fact that business owners are much more averse to risk so if the risk increases, they are not willing to provide any more of their own capital and the companies need to look for ways to increase the volume of borrowed capital to fund their activities.

Monitoring the influence of non-debt tax shield on the total indebtedness of Slovak companies seems to be interesting, as well. Although the results of several studies show a negative impact (Režñáková et al., 2010; Ameer, 2013), the results of our research show a positive correlation. It can be explained by the fact that the benefits of non-debt tax shield can only be used by those enterprises that were able to generate sufficient funds during the financial year. If the companies cannot use these advantages, the depreciation expenses would only increase their total costs. It worsens the reported financial results and leads to a decrease of own funds and the increase of external funding sources.

In the case of long-term and credit indebtedness, we find that the impact of some factors is different than in the case of total or short-term indebtedness. While the size of an enterprise influences the total and short-term indebtedness in a negative way, there is a positive correlation with the credit indebtedness (and, in the case of Slovak enterprises, also in the long-term total indebtedness), i.e. the increasing size category of companies leads to an increase in their credit indebtedness. We do believe that this result is related to the risk of individual size categories of enterprises. Big companies are generally less risky (mostly having a higher volume of collateral, diversified business activities, which reduce the risk of doing business and give them proper capital strength) than small enterprises are, so the banks are therefore more willing to provide loans especially to big companies. Similarly, we find a positive correlation between the asset structure and credit 
indebtedness. This finding can be explained by the fact that companies that have higher volume of fixed assets can use them to secure their loans. That minimizes the risk that the loan will not be eventually paid to a bank. There is also an interesting finding concerning the age of companies and the financial structure of Slovak and Czech enterprises. The impact of this factor was statistically significant only in the case of credit indebtedness, where we have found a negative correlation between the age of companies and their credit indebtedness. We assume that companies that operate in the market for a longer time have larger volumes of business activities from which they can also generate larger amount of their own funds. An important factor influencing the long-term and credit indebtedness of Slovak and Czech companies is also the profitability (there is a negative correlation between profitability and long-term and credit indebtedness).

\section{CONCLUSION}

The area of corporate finance structure and its shaping belongs to the most important areas of financial management of enterprises. Our research points to a number of findings concerning the financial structure of studied Slovak and Czech companies. First of all, the financial structure of Slovak and Czech companies is different. Slovak enterprises show significantly higher indebtedness than Czech enterprises (the total indebtedness of Slovak median enterprise is almost $16 \%$ higher than the total indebtedness of the Czech median enterprise). The ratio of debt and equity, in the case of Slovak and Czech companies, is acceptable for continental Europe, but the internal structure of indebtedness points to some specifics in the structure of the funding sources. In the case of median enterprises (both for Slovak and Czech), the debt is almost solely made up of only short-term sources. This might endanger the financial stability of especially Slovak enterprises, whose debt is substantially higher than that of Czech companies. This is due to the specifics of funding which we have pointed out in the text sooner. For these reasons, especially the appropriate liquidity should be a priority in the financial management of Slovak companies.

The aim was to examine the impact of selected internal corporate factors and external macroenvironment factors on the financial structure of enterprises and determine whether there were any differences in the action of these factors between different countries. The research has shown that the financial structure of enterprises operating either in one or in the second country is influenced mainly by internal corporate factors. The impact of external macro-environment factors on the total and short-term indebtedness has not been proved at all. Some statistically significant effect of inflation and tax rates has been found solely in the credit indebtedness of Slovak companies. Although the direct effect of macroenvironmental factors has not been proven, the selected internal corporate factors and their values are clearly related to the economic cycle (e.g., as for the profitability - companies tend to achieve higher profits in times of economic growth, while during economic recession they can even suffer a loss). In the case of selected internal business factors, we can observe the same direction of impact of these factors (profitability, size and liquidity) on the total and short-term indebtedness of the enterprises surveyed. Despite the fact that the influence of macro-environment factors has not been proved, in-depth analysis of the internal corporate factors impact revealed some differences (mainly in the intensity of the impact of these factors and in some cases also in a different direction of the impact - e. g. the influence of risk on financial structure) between companies operating in Slovakia and the Czech Republic. We believe that the variation in the intensity of the statistically significant factors can be indirectly affected by the environment in which these companies operate. At the same time, we have found out that even within specific countries, factors may behave differently - given the different levels of indebtedness surveyed (significant differences were observed especially in the size of the enterprise - where negative correlation was found in total indebtedness, while in the case of long-term and credit indebtedness a positive correlation was found). Based on the abovementioned findings, the behaviour of the enterprises in the formation of the financial structure cannot be 
unambiguously attributed to a specific theory of financial structure (since the influence of some factors was more typical for the theory of the hierarchical order, while other factors were rather typical for the compromise theory).

By analyzing the Slovak and Czech companies operating in the manufacture of machinery and equipment industry, we have been able to explain almost $20 \%$ of the total indebtedness variability (in the case of credit indebtedness, this percentage was lower). This result is comparable to that of several foreign authors - Práśilová (2012) was able to explain $11.14 \%$ of the indebtedness variability using the regression analysis, Bokpin (2009, p. 136) $12 \%$ of debt variability, Sogorb - Mira (2005, p. 453) only $8.33 \%$ of debt, while Bhaird and Lucey (2010) were able to explain even less $4.5 \%$ of the variability.

We assume that in this case of enterprises in the studied countries it would be very interesting to assess also the impact of institutional factors (e.g. law enforcement, level of corruption, protection of creditors' rights) on the financial structure of enterprises. Earlier research carried out through questionnaires (Kalusová, 2015) already pointed out to a strong influence of these factors. We assume that their inclusion in the analysis would significantly increase the percentage of the explained rate of indebtedness variability. Unfortunately, due to the high difficulty to rearrange these indicators in a measurable form, it is also very difficult to include and quantify these variables in the regression analysis.

Although we are aware of some limits as for the availability of financial statements and data, at the same time we do believe that our research results bring new interesting insights that may prompt further research in this area.

\section{ACKNOWLEDGEMENT}

The presented working paper is the output of the scientific grants VEGA n. 1/0007/19 "Asset allocation in a low interest rate environment in the financial and non-financial companies in the Slovak Republic".

\section{REFERENCES}

Archer, S., \& Karim, R. A. A. (2013). Islamic Finance. The New Regulatory Challenge. Singapore, John Wiley and Sons Singapore Pte. Ltd.

Ameer, R. (2013). Financial liberalization and firms' capital structure adjustments evidence from Southeast Asia and South America. Journal of economics and finance, 37(1), 1-32. doi: 10.1007/s12197-010-9158-3.

Bajramovič, A. (2017). Firm-specific determinants of capital structure - case of firms in Bosnia and Hercegovina. Advances in Business-Related Scientific Research Journal, 8(2), 13-24.

Bajus, R. (2008). Vývoj kapitálového trhu v SR/Development of the capital market in Slovak Republic. Biatec, 16(12), 16-20.

Bauer, P. (2004). Determinants of Capital Structure - Empirical Evidence from the Czech Republic. Finance a wivèr/Czech Journal of Economics and Finance, 54(1-2), 2-21.

Belás, J., Bartoš, P., Habánik, J., \& Novák, P. (2014). Significant Attributes of the Business Environment in Small and Meduim-Sized Enterprises. Economics and Sociology, 7(3), 22-39. doi: 10.14254/2071-789X.2014/7-3/2.

Belás, J., Bilan, Y., Demjan, V., \& Sipko, J. (2015). Entrepreneurship in SME Segment: Case Study from the Czech Republic and Slovakia. Amfiteatru Economic, 17(38), 308-326.

Bevan, A. A., \& Danbolt, J. (2002). Capital Structure and its Determinants in the United Kingdom - A Decompositional Analysis. Applied Financial economics, 12(3), 159-170. doi: 10.1080/09603100110090073.

Bhaird, C., \& Lucey, B. (2010). Determinants of Capital Structure in Irish SMEs. Small Business Economics, 35(3), 357375. doi: 10.1007/s11187-008-9162-6.

Bokpin, G. A. (2009). Macroeconomic Development and Capital Decisions of Firms - Evidence from Emerging Market Economies. Studies in Economics and Finance, 26(2), 129-142. doi: 10.1108/10867370910963055.

Booth, L., Aivazian, V., Demirguc-Kunt, A., \& Maksimovic, V. (2001). Capital Structures in Developing Countries. The Journal of Finance, 56(1), 87-130. doi: 10.1111/0022-1082.00320. 
Clayman, M. R., Fridson, M. S., \& Troughton, G. H. (2008). Corporate Finance. A Practical Approach. New York, John Wiley \& Sons.

DeAngelo, H., \& Masulis, R. (1980). Optimal capital structure under corporate and personal taxation. Journal of Financial Economics, 8(1), 3-30.

Demirgüc-Kunt, A., \& Maksimovic, V. (1998). Law, finance, and firm growth. The Journal of Finance, 53(6), 2107-2137. doi: 10.1111/0022-1082.00084.

Drobetz, W., \& Fix, R. (2003). What are the Determinants of the Capital Structure? Some evidence of Switzerland. Working paper No. 4/30.

Faccio, M., \& Xu, J. (2015). Taxes and Capital structure. Journal of financial and Quantitative analysis, 50(3), $277-300$. doi:10.1017/S0022109015000174.

Frank, M. Z., \& Goyal, V. K. (2009). Capital Structure Decisions: Which Factors are Reliably Important? Financial Management, 38(1), 1-37. doi:10.1111/j.1755-053X.2009.01026.x.

Hailu, G., Jeffrey, S., \& Goddard, E. (2007). Capital Structure, Firm size and efficiency: The Case of Farm Petroleum and Animal Feed Co-operatives in Canada. Agricultural Finance Review, 67(2), $279-293$. doi:10.1108/00214660780001.

Hall, G., Hutchinson, P., \& Michaelas, N. (2000). Industry Effects on the Determinants of Unquoted SMEs Capital Structure. International Journal of the Economics of Business, 7(3), 297-312. doi: 10.1080/13571510050197203.

Harrison, B., \& Widjaja, T. W. (2014). The Determinants of Capital Structure: Comparison between Before and After Financial Crisis. Economic Issues, 19(2), 55-82.

Herciu, M., \& Ogrean, C. 2017. Does capital structure influence company profitability? Studies in Business and Economics,12(3), 51-63. doi:10.1515/sbe-2017-0036.

Heyman, D., Deloof, M., \& Ooghe, H. (2008). The Financial Structure of Private Held Belgian Firms. Small Business Economics, 3(3), 301-313. doi:10.1007/s11187-006-9031-0.

Hrvol’ová, B., \& Badura, P. (2014). Analýza finančných trhov: praktikum/Financial markets analysis: Pactice. Bratislava, Vydavatel'stvo EKONÓM.

Jaisinghani, D., \& Kanjilal, K. (2017). Non-linear dynamics of size, capital structure and profitability: Empirical evidence from Indian manufacturing sector. Asia Pacific Management Review, 22(3), 159-165. doi: 10.1016/j.apmrv.2016.12.003. doi: 10.1016/j.apmrv.2016.12.003.

Jõeveer, K. (2005). What Do We Know about the Capital Structure of Small Firms. Working paper series. Praha, CERGE-EI.

Jõeveer, K. (2006). Sources of Capital Structure: Evidence from Transition Countries. Working paper series. Prague, CERGE-EI.

Jong, A., Kabir, R., \& Nguyen, T. T. (2008). Capital Structure around the World: The Roles of Firm- and Countryspecific Determinants. Journal of Banking and Finance, 32(9), 1954-1969. doi: 10.1016/j.jbankfin.2007.12.034.

Kakilli Acaravci, S. (2015). The Determinants of Capital Structure: Evidence from the Turkish Manufacturing Sector. International Journal of Economics and Financial Issues, 5(1), 158-171.

Kalusová, L. (2015). Dopady podnikatel'ského prostredia na rozhodovanie o finančnej štruktúre malých a stredných podnikov/ The Impact of business environment on financial structure decisions of SMEs. Ekonomika a manažment/Economics and Management, 12(1), 25-37.

Klapper, L. F., Sarria-Allende, V., \& Sulla, V. (2002). Small and Medium-size Enterprise Financing in Eastern Europe. $\begin{array}{llll}\text { Retrieved } \quad \text { March } & \text { 15, 2018, from }\end{array}$ https://pdfs.semanticscholar.org/5032/57deb5d3249defb83766f101af618a70c328.pdf

Korajaczyk, R. A., \& Levy, A. (2003). Capital Structure Choice: Macroeconomic Conditions and Financial Constraints. Journal of Financial Economics, 68(1), 75-109. doi: 10.1016/S0304-405X(02)00249-0

Kozubíková, L., Belás, J., Bilan, Y., \& Bartoš, P. (2015). Personal characteristics of entrepreneurs in the context of perception and management of business risk in the SME segment. Economics and Sociology, 18(1), 41-54. doi: 10.14254/2071- 789X.2015/8-1/4.

Krištofík, P. (2002). Determinanty kapitálovej štruktúry a finančného rozhodovania v podmienkach slovenských podnikov/ Determinants of capital structure and financial decision-making in Slovak enterprises. Ekonomický časopis/Journal of Economics, 50(2), 197-216. 
Moosa, I., \& Li, L. (2012). Firm_specific Factors as Determinants of Capital Structure: Evidence From Indonesia. Review of Pacific Basin Financial Markets and Policies, 15(2), 1-17. doi: 10.1142/S021909151150007X.

Nguyen, T. D. K., \& Ramachandran, N. (2006). Capital Structure in Small and Medium-sized Enterprises: The Case of Vietnam. ASEAN Economic Bulletin, 3(2), 192-211. doi: 10.1353/ase.2007.0006.

Nivorožkin, E. (2004). The Dynamics of Capital Structure in Transition Economies. Economics of Planning, 37(1), 25-45. doi: 10.1007/s10644-004-1056-2.

Öztekin, O. (2015). Capital structure decisions around the World: which factors are reliably important? Journal of financial and quantitative analysis, 50(3), 301-323. doi: 10.1017/S0022109014000660.

Pacáková, V. et al. (20093). Štatistika pre ekonómov/Statistics for Economists. Bratislava, edícia EKONÓMIA.

Prášilová, P. (2012). Determinanty kapitálové struktury českých podniků/Determinants of capital structure within Czech companies. E + M. Ekonomie a management/E+M Economics and Management, 15(1), 89-104.

Ramalho, J. S., \& da Silva, J. V. (2009). A two-part fractional regression model for the financial leverage decisions of micro, small, medium and large firms. Quantitative Finance, 9(5), 621-636. doi: 10.1080/14697680802448777.

Režňáková, M., Svoboda, P., \& Polednáková, A. (2010). Determinants of Capital Structure: Empirical Evidence from Slovakia. Ekonomický časopis/Journal of Economics, 58(3), 237-250.

Salameh,H. M., Al-Zubi, K. A., \& Al-Zu'bi, B. (2012). Capital Structure Determinants and Financial Performance Analytical Study in Saudi Arabia Market 2004-2009. International Journal of Economic Perspective, 6(4), 18-33.

Singla, R. K. (2008 - 2009). Business Studies. New Delhi, V. K. Enterprises.

Sivák, R. (2001). Kapitálová a finančná štruktúra, zadlženost' a platobná neschopnost' - problémy podnikovej sféry v Slovenskej republike/ Capital and financial structure, insolvency and debts problems of corporate sphere in the Slovak Republic. Ekonomika a spolocnost'/ The Journal of economics and social research, 2(2), 140-148.

Sogorb-Mira, F. (2005). How SME uniqueness affects capital structure: Evidence from a 1994-1998 Spanish data panel. Small Business Economics, 25(5), 447-457. doi:101007/s11187-004-6486-8.

Titman, S., \& Wessels, R. (1988). The determinants of capital structure choice. The Journal of Finance, 43(1), 1-19. doi:10.1111/j.1540-6261.1988.tb02585.x.

Vatavu, S. (2013). Determinants of Corporate Debt Ratios: Evidence from Manufacturing Companies Listed on the Bucharest Stock Exchange. Timisoara Journal of Economics and Business, 6(20), 99-126. 